\title{
HUSBAND'S SUPPORT AND PARITIES WITH SELECTION OF INJECTED CONTRACEPTION OF KB ACCEPTORS IN PUSKESMAS BALOI PERMAI
}

\author{
Luis Yulia ${ }^{1}$, Bratasena $^{2}$ \\ luisyulia@univbatam.ac.id', bratasena@univbatam.ac.id ${ }^{\mathbf{2}}$ \\ Professional Doctor Study Program, Faculty of Medicine, Batam University ${ }^{1}$ \\ Medical Education Study Program, Faculty of Medicine, University of Batam ${ }^{2}$ \\ Jl. Abulyatama No 5
}

\begin{abstract}
Abstact
Background : The increasing number of Indonesia's population is the impact of increasing birth rates. KB Injection is the most widely used family planning by women of reproductive age (WUS). The height of the 3-month injection family planning acceptors is influenced by several factors, namely age, education, occupation, income, and parietas. The purpose of this study was to determine the relationship between husband and parietas support with the choice of injection contraception.

Method : The research method is analytical survey with cross sectional approach. Conducted at the Baloi Permai puskesmas, the study was conducted for 6 months, the population in this study were all injection family planning acceptors in the working area of the Baloi Pemai Puskesmas as many as 6,219 acceptors. With a sample size of 98 people, sampling using purposive sample with research instruments using a questionnaire and analyzed using Chi Square.

Result : The results of the parity study of acceptors who chose the most injection contraceptive were the category of children 2-4 years as many as 57 people (58.2\%). Contraceptive family planning acceptors who chose injection contraceptives the most were injection contraceptives for 3 months as many as 51 respondents $(52.0 \%)$. with a p value $=0.025$.

Conclusion : Suggestions for agat acceptors can find out the advantages and disadvantages of contraceptives to be used and should ask for an explanation from health workers to provide assistance in choosing contraceptives so that the family planning used is truly safe to use even in the long term
\end{abstract}

\section{Keywords : Husband Support, Parity, KB injection}

\section{INTRODUCTION}

Indonesia is a developing country which has a problem in population numbers, in general, the main problems in the population facing Indonesia, namely, a large population with a relatively high population growth rate, unequal population distribution, a young population structure, a high quality of population. still needs to be improved (Sulistyawati, 2011). The high rate of growth that is not accompanied by an increase in the quality of the population will affect the level of life and welfare of the population.

According to the publication of the Central Statistics Agency (BPS) in August 2010, the total population of Indonesia based on the results of this census was $237,556,363$ people, consisting of 119,507.58 men and 118,048,783 women. Therefore, direct efforts to reduce the birth rate still need to be increased

One of the methods used to suppress the population growth rate is through controlling the birth rate. The government through the Population and Family Planning Agency (BKKBN) has implemented a family planning program that began in 1970 (BKKBN, 2012)

The family planning service program (KB) has an important meaning in realizing a prosperous Indonesian human being, in addition to education and health programs. Awareness of the importance of contraception in Indonesia 
still needs to be increased to prevent an increase in the population population in Indonesia in 2015 (BKKBN, 2008)

The largest use of family planning in Indonesia is injection (31.6\%), pill (13.2\%), spiral (4.8\%), implants $(2.8 \%)$, condoms (1.3\%), MOW (3, $1 \%)$, MOP $(0.2 \%)$, periodic abstinence $(1.5 \%)$ interrupted intercourse $(2.2 \%)$ and other methods (4.4\%). Whereas in countries, the most popular methods are oral contraceptives (16\%), male condoms (14\%).and interuptus coitus $(13 \%)$

Injectable contraceptives are one of the most widely used contraceptive methods in Indonesia. The use of hormonal contraceptives as a means of contraception has increased dramatically. Contraceptive methods that have high effectiveness both 1 month and 3 months injections. The choice of contraception by women of childbearing age who is in accordance with the wishes is very important, one of the contraceptives that are widely chosen is the contraceptive injection for either 1 month or 3 months, because injection is a practical, safe, cheap contraceptive tool. Factors that influence the use of injectable family planning include: Knowledge, Education, Age, Information Media, Availability of Tools, Health Care Workers, Support from Husbands. (Astuti, 2010)

Most of the family planning acceptors choose injection contraception because they only need to do it once every 1-3 months and do not need to go through a prosthetic process like during spiral insertion. Injectable contraception is considered effective, its use is practical, the price is relatively cheap and safe (Uliyah, 2010). 3-month injection contraception also does not affect the breastfeeding process, it does not depend on the factors of intercourse, it can be used by all women of reproductive age (Saifuddin, 2010)

According to data from the BKKBN (National Population and Family Planning Board) in the Riau Islands Province in December 2013, the number of active injection family planning participants, namely Bintan was 7003
(53.29\%), Karimun was 15,005 (45.57\%), Natuna was 3,950 (61.37\%), Lingga as much as $5,776(51.75 \%)$, Anambas Islands as much as $3,304(50.47 \%)$, Batam City as much as 55,811 (37,952\%), Tanjung Pinang City as much as 4,579 (57.76\%) (BKKBN , 2013)

Based on data from the Batam City health office in 2015, 167,700 active family planning participants were recorded, including 7,456 (4.4\%) Intra Uterine Device (IUD), 19 (0.0\%) Male Operative Method (MOP). Operative Women (MOW) as many as $625(0.4 \%)$, implants as many as 5,244 (3.1\%), condoms as many as $12,493(7.4 \%)$, injections as many as $86,638(51.7 \%)$, and pills as many as 55,225 (32 , 9\%).) Based on data from the Batam City Health Office in 2015, the highest number of active injection family planning participants was 12,392 at Baloi Permai Health Center (67.1\%) (Dinkes, 2015). Based on the initial survey at the Baloi Permai Health Center, in 2016 the number of active injection family planning participants was 6,219 acceptors.

There are still a lot of reproductive health problems that need to be studied, not only about the reproductive organs, but there are several aspects, one of which is contraception. Currently, there are many methods or means of contraception available including: IUD, injection, pill, implant, contraception, condom. One of the popular contraceptives in Indonesia is injection contraception. The contraceptives used were Norestisterone Enentat (NETEN), Depo Medroxy Progesterone Acetate (DMPA) and Cyclofem (BKKBN, 2004).

Injectable contraceptives have both advantages and side effects. The advantage of injectable contraceptives in general is that they are highly effective during the first year of use. The advantages of 1-month injection contraception include long-term contraceptive effect, reducing the amount of menstrual bleeding, reducing menstrual pain and not disturbing the husband and wife relationship. The advantages of the 3-month injection include having a longterm contraceptive effect, reducing the amount of menstrual bleeding, reducing menstrual pain, not disturbing the husband and wife 
relationship and not affecting the production of breast milk. Injectable contraceptives have several side effects including changes in menstrual patterns, nausea, dizziness and mild breast pain. The side effect most often complained of by injection contraceptive acceptors was changes in menstrual patterns. In general, the acceptor's menstrual cycle can be shortened or prolonged, more or less bleeding, irregular bleeding or spotting and even no menstruation at all (Saifudin, 2006).

In theory, 1 month injection contraceptive acceptors can experience a normal menstrual pattern and some may experience changes in menstrual patterns. The 3-month injection contraceptive acceptors may experience menstrual pattern disorders, such as short or prolonged menstrual cycles, heavy or small bleeding, irregular bleeding or spotting and even no menstruation at all (Amenorhoe) (Saifudin, 2006).

Based on previous research conducted by Normalasari (2012) with the title of factors related to the choice of contraceptive injection for contraceptives at the Sambau Community Health Center in Batam, it is known that there are 99 respondents, 69 respondents $(70 \%)$ with high education and 30 with low education. respondents $(30 \%)$, because those with higher education already know a lot of information and broad insights, either directly or indirectly.

The high acceptors of family planning in the selection of injection contraceptives certainly cannot be separated from the factors that influence family planning acceptors in choosing the contraceptive method. These factors include partner factors, health factors, and contraceptive method factors (Hartanto, 2002).

Based on the descriptions above, the authors are interested in conducting research with the title "Husband support and parity with the high acceptors of injection contraceptives at Puskesmas Baloi permai, Batam City"

\section{RESEARCH PURPOSES}

To find out the frequency distribution of family planning acceptor factors choosing kb injection in terms of husband and parietal support and the relationship between husband and parietas support with the selection of injection contraceptives

\section{RESEARCH METHODS}

The research method is analytical survey with cross sectional approach. Conducted at the Baloi Permai puskesmas, the study was conducted for 6 months, the population in this study were all injection family planning acceptors in the working area of the Baloi Pemai Puskesmas as many as 6,219 acceptors. With a sample size of 98 people, sampling using purposive sample with research instruments using a questionnaire and analyzed using Chi Square

\section{RESEARCH RESULT}

From the results of research on 98 respondents, it was found:

The frequency distribution of acceptors based on good husband's support was 71 respondents (72.4\%), 27 respondents (27.6\%) were less likely to get husbands. The frequency distribution of acceptors based on the parity number of 2-4 children was 57 respondents $(58.2 \%)$, parietas 1 was 30 respondents $(30.6 \%)$ and those who had> 5 children were 11 respondents $(11.2 \%)$

The choice of contraceptive contraceptives for family planning acceptors who chose the most injection contraceptives was 3-month injection contraception as many as 51 respondents (52.0\%, and those using 1-month injection contraception were 47 respondents $(48.0 \%)$

Based on the results of the bivariate test, it was found that respondents with good husband's support and the most chose 1 month contraception were 39 respondents (55.0\%), respondents with less husband's support chose 19 respondents $(70.3 \%)$ with the highest pvalue. -value 0.025 ( $\mathrm{p}$ value $<0.05$ ), which means that there is a relationship between husband's support and the choice of injection contraceptives 
Respondents with category 1 children who mostly chose 1 month contraception were 19 respondents (63.3\%), respondents with category 2-4 children who most chose 3 months injection contraception were 33 respondents (57.9\%), respondents with categories> 57 respondents $(63.7 \%)$ chose the most 3-month injection contraceptives with a p-value of 0.412 (p-value> 0.05), which means that there is no relationship between parietas and the choice of injection contraception.

\section{DISCUSSION}

\section{Husband's support with the choice of injection contraceptives}

From the results of research conducted by researchers, the frequency distribution of acceptors choosing injection contraceptives based on husband's support was 71 people (72.4\%) in good category, and 27 people $(27.6 \%)$ in poor category. Based on the results of the bivariate test, it was found that respondents with good husband's support and the most preferred 1 month contraception were 39 respondents $(55.0 \%)$, respondents with less husband's support chose 19 respondents $(70.3 \%)$ with the highest p-value. -value 0.025 ( $p$ value $<0.05$ ), which means that there is a relationship between husband's support and the choice of injection contraception. This explains that many mothers who use husband's contraception provide good support. This is because the husband as the head of the family is the person who plays a major role and is very dominant in making decisions related to the needs or problems that occur in the family, including in terms of family planning. In terms of using injectable contraceptives the wife requires the husband's consent, opinion and support, from the results of the interview, it is known that the decision to use injectable contraceptives is highly dependent on the husband's consent.

Husband's support consists of 4 forms, namely informational support, assessment, instrumental, and emotional. The wife cannot use contraception without the husband's cooperation and mutual trust. Ideally married couples should choose the best contraceptive method, cooperate with each other in use, pay expenses for contraception, and pay attention to signs of dangers of use (Hartanto, 2010).

Roles such as participating in a consultation with a health worker when the wife is going to use contraception, reminding the wife of a schedule for taking medication or a schedule for control, reminding the wife of things that should not be done when using contraceptives, etc. contraception. The size of the husband's role will greatly help him and the husband will increasingly realize that reproductive health problems are not only a woman's (wife) problem.

The results of this study are in accordance with research conducted by Putriningrum where in this study it was stated that $100 \%$ of respondents before determining contraception were discussed with their husbands and with the husband's permission. Choosing a contraceptive can not be separated from the existence of a joint commitment with her husband.

In this study, it was stated that $100 \%$ of respondents discussed contraception with their husbands and with the husband's permission. Choosing a contraceptive can not be separated from the existence of a joint commitment with her husband.This research is in line with the research conducted by Purba (2008) in Rambah Samo District and Mahu's (2011) research at the Kedungmundu Public Health Center, Semarang which shows that there is a relationship between husband's support and the use of injectable contraceptives because in terms of using injectable contraceptives the wife requires approval, opinion and support. husband, from the results of the interview it is known that the decision to use injectable contraception is very dependent on the husband's consent

Support from husbands who tend to be more supportive of family planning acceptors in choosing hormonal contraceptives, especially injectable contraceptives and pills, because hormonal contraceptives are relatively inexpensive so they are easily accessible 
economically, and are quite effective and do not interfere with sexual relations.

\section{Parietas with possession of injectable contraceptives}

From the results of research conducted by researchers, the frequency distribution of acceptors choosing injection contraceptives based on maternal parity for category 1 children were 30 people $(30.7 \%)$, categories $2-4$ children were 57 people $(58.1 \%)$, and categories $>5$ children were as many as 11 people (11.2\%). This explains that many mothers who use injectable contraceptives have 2-4 children. Respondents with category 1 children who mostly chose 1 month contraception were 19 respondents (63.3\%), respondents with category 2-4 children who most chose 3 months injection contraception were 33 respondents (57.9\%), respondents with categories> 57 respondents $(63.7 \%)$ chose the most 3-month injection contraceptives $(63.7 \%)$ with a p-value of 0.412 (p-value> 0.05), which means that there is no relationship between parietas and the choice of injection contraception.

Based on the results of research conducted in the field, it can be explained that most mothers who have 2-4 children use injectable contraceptives. This is because mothers who are going to use contraception must consider the number of children with the aim of spacing out births and delaying pregnancy, so the right choice of contraception is injection contraception. It should be seen from the number of your children who are more than 2 , it is highly recommended to use a more effective and long-term contraceptive device such as the IUD (Intra Uterine Device).

Most of the respondents have enough living children (anak 2 children) the reason they are delaying having children is because they want to have a small, happy and prosperous family and do not want to be burdened when they have a large number of children such as not being able to pay for children's needs when they are adults, unable to send their children to school. and so forth. However, there are also families who want a large number of children, on the grounds that many children have a lot of sustenance and if they have many children, they can help parents in finding additional income for their parents. This is in accordance with Rizali's (2013) research that the number of children affects the choice of 3-month injection contraceptives

The results of this study are also in line with the results of Wahyuni's (2015) study that the parietas factor or the number of children has no effect on the high choice of 3-month injection family planning. In this study most of the respondents were multiparous, namely having 2-4 children, usually mothers with more than 3 children chose long-term contraceptives such as IUD or implants, but in fact many of them chose to use 3-month injection KB. They said they were more comfortable using injectable KB 3 months because it has few side effects and does not interfere with the menstrual cycle.

Based on the results of research conducted in the field, it can be explained that culture is still held and practiced in the daily life of a child which has a high value for the family, especially boys who are considered to be the next generation so that the family will continue to try to give birth to a boy. And on the contrary, if in the family all children are male, the family wants to have a daughter on the grounds that there is a woman in the family to accompany her mother, some of the things mentioned above are factors that cause families to have more than two children. So that mothers who have children 2-4 people choose to use injectable contraceptives which are to spacing pregnancies not to terminate pregnancies such as sterilization

This is in accordance with the theory of Hartanto (2004) which states that in couples with a small number of living children, there is a tendency to use contraceptive methods with low effectiveness and in large numbers of living children there is a tendency to use contraceptive methods with high effectiveness. Parity is the number of births that the mother has experienced, both live births and stillbirths, but does not include abortions. The high parity of the mother will have an unfavorable impact, such as the risk during pregnancy and 
childbirth, therefore the role of family planning is very important in planning the number of families.

Based on the theory above, it can be concluded that this theory is contrary to the results of the research conducted that in the study there was no relationship between parity and contraceptive choice because the majority of mothers who chose injection contraception had 2 children or more, while the theory stated that the number of or more should choose very high effectiveness contraceptives such as the IUD (Intra Uterine Device).

This research is in line with that conducted by Normalasari (2012) with the title factors related to the choice of injection contraceptives, the $\mathrm{p}$ value is 0.924 (meaning the $p$ value is greater than 0.05 ) so that means Ho is accepted, meaning that there is no significant relationship between parity mothers with birth control contraceptive choices. Because in the selection of injection contraceptives, most who have $>2$ children, after being tested using the Chi-square $\mathrm{p}$ value is greater

\section{CONCLUSION}

a. The frequency distribution of acceptors based on good husband's support was 71 respondents $(72.4 \%)$

b. The frequency distribution of acceptors based on the parity number of 2-4 children was 57 respondents $(58.2 \%)$

c. There is a relationship between husband's support and the choice of injection contraception, with a $p$ value $=0.025$

$\mathrm{d}$. There is no relationship between maternal parity and injection contraceptive choice, with a $\mathrm{p}$ value $=0.412$

\section{SUGGESTION}

From the results of research conducted on 98 family planning acceptor respondents who chose injection contraceptives, the following suggestions were obtained:

\section{For the acceptor}

It is hoped that you can find out the advantages and disadvantages of the contraceptive device that will be used and should ask for an explanation from the health worker to provide assistance in choosing a contraceptive device so that the family planning used is truly safe to use even in the long term.

2. For Puskesmas Baloi Permai

It is hoped that health workers, especially midwives, can provide information about contraceptive devices that will be used by injection contraceptive acceptors, especially in high-risk age groups, and advise users of injection contraceptives to use long-term family planning.

3. For Educational Institutions

It is hoped that the results of this research can be an additional means of learning and knowledge, especially for students of the midwifery study program.

4. For other researchers

Further research is carried out with different research methods, different variables, the number of population and the research sample is more so that better results will be obtained.

\section{DAFTAR PUSTAKA}

Anggraini, Y dan Martini. (2012). Pelayanan Keluarga Berencana. Yogyakarta: Rohima Press

BKKBN, 2004. Pengguna Kontrassepsi Efektif. Jakarta:BKKBN tersedia dalam:

http://bkkbnnasional.com/2004/keluar gaberencana.html

, (2010). Laporan Pencapaian Peserta KB Aktif Tahun 2010, Medan : BKKBN Kota Medan

. (2012). Pengguna Kontrasepsi Efektif. Jakarta : BKKBN tersedia dalam:

http://bkkbnnasional.com/2004/keluar gaberencana.html (Diakses, 25 Maret 2015)

Dinas Kesehatan Batam, (2015), Profil Kesehatan Kota Batam Tahun 2015, Batam: Dinas Kesehatan Kota Batam

Faridah, Umi(2014). Hubungan Antara Dukungan Suami dengan Pemilihan Metode Kontrasepsi Pasca Persalinan. Jurnal Kebidanan Dan Keperawtan, Vol 5, No 1 Juni 2014:49-58: Yogyakarta 
Gunawan, Ary. (2000). Sosiologi Pendidikan: Suatu Analisis Sosiologi Tentang Pelbagai Problem Pendidikan. Jakarta: Rineka Cipta.

Handayani, Sri. (2010). Buku Ajar Pelayanan Keluarga Berencana. Yogyakarta: Pustaka Rihama

Hartanto, H. (2004). Keluarga Berencana dan Kontrasepsi. Jakarta: Pustaka Sinar Harapan

(2012). Keluarga Berencana dan Kontrasepsi, Jakarta: Pustaka Sinar Harapan

Irianto, K. (2014). Pelayanan keluarga berencana: Dua anak cukup. Bandung: Alfabeta

Irmayanti, (2007). Pengetahuan. http:/id.wikipedia.org/wiki/pengetahua $\mathrm{n}$

Gustikawati, D.A. 2014, Faktor Pendukung dan Penghambat Istri PUS dalam Penggunaan Alat Kontrasepsi Implant di Puskesmas 1 Denpasar Utara.Publikas Penelitian.Denpasar: Jurusan Kesehatan Masyarakat Universitas Udaya

Manuaba IBG (2008). Ilmu kebidanan, penyakit kandungan dan keluarga berencana untuk pendidikan bidan. Jakarta:Salemba Medika

Normalasari. (2012), Faktor-Faktor Yang Berhubungan Dengan Pemilihan Kontrasepsi KB Suntik, Karya Tulis Ilmiah Tidak Diterbitkan, Universitas Batam, Kota Batam

Notoatmodjo, Soekidjo, (2003), Ilmu Kesehatan Masyarakat, Rineka Cipta, Jakarta

(2010). Metodologi Penelitian Kesehatan. Jakarta: Rineka Cipta. . (2010). Pendidikan dan Perilaku

Kesehatan. Jakarta : Rineka Cipta

Nursalam, (2008), Konsep dan Penerapan Metodologi Penelitian Ilmu Keperawatan, Edisi Pertama, Salemba Medika: Jakarta
Pinem, S., (2009), Kesehatan Reproduksi dan Kontrasepsi, Jakarta: Trans Info Media

Prawirohardjo, Sarwono., (2005).Ilmu kebidanan.Jakarta : Yayasan Bina Pustaka

Priyoto. (2014). Konsep manajemen stres. Yogyakarta : Nuha Medika

Putriningrum, (2010). Faktor-Faktor Yang Mempengaruhi Ibu Dalam Pemilihan Kontrasepsi KB Suntik. Karya Tulis Ilmiah diterbitkan. Surakarta

Rizali, I.R., Ikhsan, M, Salamah, U 2013,'Faktor yangBerhubungan dengan Pemilihan Alat KontrasepsiSuntik di Kelurahan Mattoangin Kecamatan MarisoKota Makassar'. http://

journal.unhas.ac.id/index.php/mkmi/article/vie w/467, Vo.9, No. 3

Rumengan, Jimmy. (2008). Metodologi penelitian kesehatan. Bandung: Citapustaka Media Perintis

Saifuddin, A. (2008). Panduan Praktis Pelayanan Kontrasepsi. Jakarta: Yayasan Bina Pustaka-Sarwono Prawirohardjo.

Sugiyono, (2008). Metode Penelitian Kunatitatif Kualitatif dan $R \& D$. Bandung Alfabeta.

Sujiyatini dkk. (2011).Catatan Asuhan Ibu Nifas.Yogyakarta:Nuha medika

Sulistyawati, Ari. (2013). Pelayanan Keluarga Berencana. Jakarta : Salemba Medika

$$
\text { (2013). Pelayanan Keluarga }
$$

Berencana. Salemba Medika ; Jakarta

Suparyanto. (2011). Wanita Usia Subur. Wordpress. Com Diakses tanggal 19 Oktober 2011

Yuliasari. (2010). Hubungan Tingkat Pengetahuan Ibu dengan Pemilihan Keluarga Berencana. Karya Tulis Ilmiah diterbitkan, RSKIA Surakarta

Vidayanti. (2007), Faktor-faktor yang Berhubungan Dengan Pemilihan Kontrasepsi Suntik, Karya Tulis Ilmiah Diterbitkan, (Diakses, 17 Agustus 2015) 
ZONA KEDOKTERAN - Vol. 10 No. 3 September 2020

Wiknjosastro, Hanifa, (2006), Ilmu Kebidanan, Edisi Ketiga, Ja

karta : YBP-SP 